\title{
Physiochemical Analysis of Water from Some Selected Boreholes and Hand dug wells in Kaltungo, Gombe State, Northeast, Nigeria
}

\author{
S. Saleh, A. Nur, S. Yusuf, and A. N. Kilian
}

\section{ABSTRACT}

\begin{abstract}
The occurrence, storage, and distribution of groundwater in the Precambrian basement complex are influenced by different geological factors. Groundwater is never chemically pure; dissolution of substances takes place in the course of its percolation through the rocks leading to its acquisition of some of their chemical constituents. The purpose of the investigation is to determine the suitability of groundwater for domestic and industrial usage. Four samples were collected from boreholes and six from hand dug wells. Samples were analyzed chemically by using the DR/2010 Spectrophotometer and Digital Titrator while physical parameters where determine using the pH meter, and TDS meter. Hydraulic conductivity and transmissivity results range from $4.24 \mathrm{~m} / \mathrm{day}$ to $72.63 \mathrm{~m} /$ day and $23.84 \mathrm{~m}^{2} /$ day to $964.0 \mathrm{~m}^{2} /$ day. The geochemical result obtained from the analysis of $\mathbf{1 0}$ water samples in the study area with an average values $\mathrm{pH} 6.82$. Temp. $31^{\circ} \mathrm{C}$, colour (TCU) 1.00 , Turbidity 1.2 , Conductivity $174.5 \mu \mathrm{s} / \mathrm{cm}$, TDS $87.7 \mathrm{mg} / \mathrm{l}$, which revealed that the water physical parameters are below the WHO permissible value. Total Hardness $161.7 \mathrm{mg} / \mathrm{l}, \mathrm{Ca}^{2+}$ 64.3mg/l Na${ }^{+} 68.8 \mathrm{mg} / \mathrm{l}, \mathrm{NO}_{3}{ }^{+} \mathrm{0.1} \mathrm{mg} / \mathrm{l} \mathrm{Fe}{ }^{2+} 0.04 \mathrm{mg} / \mathrm{l} \mathrm{CO}$ $96.4 \mathrm{mg} / \mathrm{l}$ Sulphate $47 \mathrm{mg} / \mathrm{l} \mathrm{Cl}-96 \mathrm{mg} / \mathrm{l}$ and $\mathrm{F}^{-} 0.3 \mathrm{mg} / \mathrm{l}$. Results obtained of the water analysis reveals that the concentration of Total Hardness and $F^{-}$ in some parts of the study area are above the permissible standard for drinking water WHO Standard. Therefore, the water in the affected part of the study area should be subjected to proper treatment. The groundwater flow direction is from higher surface elevation to lower surface elevation.
\end{abstract}

Groundwater, Hydraulic head.

\section{INTRODUCTION}

Water is the primary need of every living thing on this planet (earth) which is essential for sustaining life. The largest source of fresh water lies underground. The need for analysis of water physically, chemically is to know the acceptable quality and adequate supply of water for domestic and industrial purposes for enhanced socio-economic growth and development should be pursued.

Groundwater simply implies water occupying all the voids within a geologic stratum or within fractured zones and is known to occur more widely than surface water [9]. Over $90 \%$ of fresh water available at any given moment on the earth lies beneath the land surface. In the study area, seasonal streams, rivers, hand-dug wells, and boreholes are the main sources of water supply. The area is also known to be associated with cases of dental fluorosis.

Groundwater percolate and filtered through the soil and acquires some of these dissolved chemical constituents. If the thickness of the soil filter is thin, dissolved chemical constituent in water determine its usage for various purposes. The concentrations of the dissolved constituent are compared
Published Online: February 14, 2022

ISSN: $2684-446 \mathrm{X}$

DOI : 10.24018/ejgeo.2022.3.1.213

\section{S. Saleh *}

Department of Pure and Applied Physics, Federal University Wukari, Taraba, Nigeria.

(e-mail: samuels864@gmail.com)

A. Nur

Department of Geology, Modibbo Adama University of Technology Yola, Nigeria.

(e-mail: anur@mautech.edu.ng)

S. Yusuf

Department of Pure and Applied Physics,

Federal University Wukari, Taraba, Nigeria.

(e-mail: yusufsani480@gmail.com)

A. N. Kilian

Department of Pure and Applied Physics,

Federal University Wukari, Taraba,

Nigeria.

(e-mail: oklaayuni@gmail.com)

*Corresponding Author to the standards of World Health Organization (WHO).

This work is carried out in order to investigate and obtain the groundwater potential of Kaltungo and environs. This will be achieving by determining the suitability of groundwater in some part of Kaltungo area for human consumption and industrial purposes and also by evaluating the possible sources of groundwater pollution and provides solution to the problems.

The area is characterized by two distinct seasons, the rainy and the dry season. The rainy season, which is usually longer and associated with intermitted heavy rainfall in months of July and August, begins around late April to early October. The dry season is relatively shorter and last from November to March in many cases. It is accompanied by hammattan, a period is associated with temperature drop $\left(31^{\circ} \mathrm{C}-21^{\circ} \mathrm{C}\right)$ which occurs between the months of November, and February [4].

Kaltungo lies within the Gongola arm of the upper Benue Trough of North Eastern Nigeria (Fig. 1) and constitute part of sheet 173 Kaltungo Northeast on a scale of $(1: 50,000)$. Lying between latitude $9^{\circ} 45^{\prime}$ and $9^{\circ} 50^{\prime}$ and longitude $11^{\circ} 15^{\prime}$ and $11^{\circ} 20^{\prime}$. The study area covers an area extent of $84.03 \mathrm{~km}^{2}$. The area is semi-arid environment which is characterized 
with sparse vegetation, stunted trees mostly Kanje, with shrubs and thorny bushes at the stream banks. The vegetation is described by Sahel Savannah.

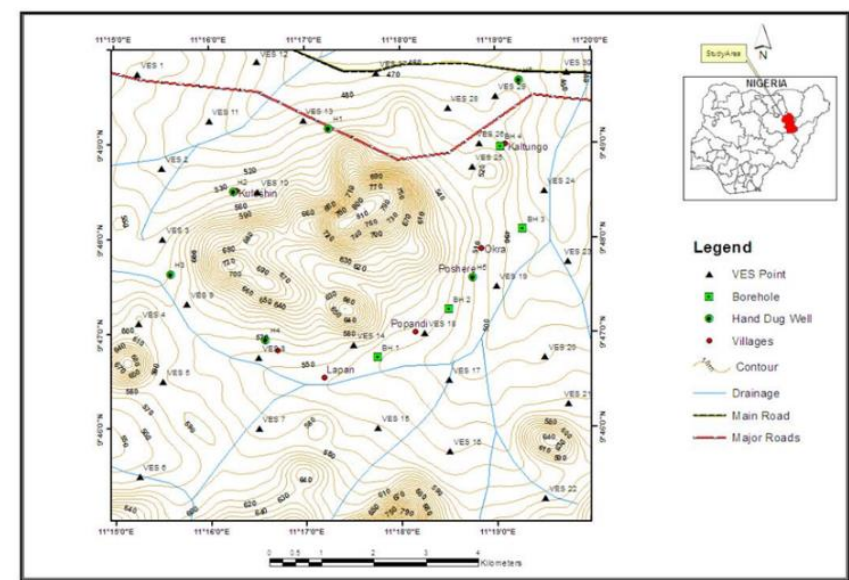

Fig. 1. Topographic Map of the Study Area (Modified After Federal Survey of Nigeria Topo-sheet 173NE of 1976)

\section{GEOLOGY AND HYDROGEOLOGY}

Kaltungo falls within the Gongola arm of the upper Benue trough of Nigeria, the area is underlain by basement complex rocks consisting of the older granite, coarse porphritic granite and biotite granite spread all over the area and believe to have been emplaced during the Pan African Orogeny (Fig. 2). The area has been described as part of the Nigerian Basement Complex consisting of gneisses and migmatites (Precambrian-lower Paleozoic) which were intruded in various places by a relatively younger suit of rocks, the older granite [3].

Bima Formation underlies the southern part of the mapped area (Fig. 2). In the Benue Trough, the oldest rock unit is the Bima Sandstones lie uncomfortably on the Precambrian basement complex rocks. The Bima Sandstone was deposited during the late Aptian to middle Albian [1]. Generally, the Sandstone in this Formation are feldspathic Sandstone.

Biotite granite covers the central part of the study area, the color of the biotite granite ranges from white to grey, which is leucocratic. The biotite is flaky in structure, black to grey colored. Some of the biotite granite occurred as boulders. These granites are also found in the western part, southern part and eastern part of the study area respectively. Biotite granite have granular texture with wide range of grain sizes.

The porphyritic Granite in the study area ranges from medium to coarse grained with minor variations in texture ranging from granitic to granophyric. The major constituents of the porphyritic granite are K-felspers, biotite and quartz. The color of the porphyritic granite ranges mostly from white to grey, which is leucocratic. The porphyritic and biotite granites belong to the older granite of the Nigerian basement complex. The porphyritic granites are coarse to very coarse grained with large white or pink prismatic phenocysts of microline.

Migmatite gneiss occupy a small portion of the study area (Fig. 2), the outcrop is at the Southwestern part of the study area. The outcrop was of low relief when compared to biotite granites. Migmatite gneiss is foliated, that is, there is the alignment of light and dark minerals. The leucosome is the lightest coloured part of migmatite gneiss while melanosome is the darker part. The structural features observed on the rock are mostly fracture/joints and foliation.

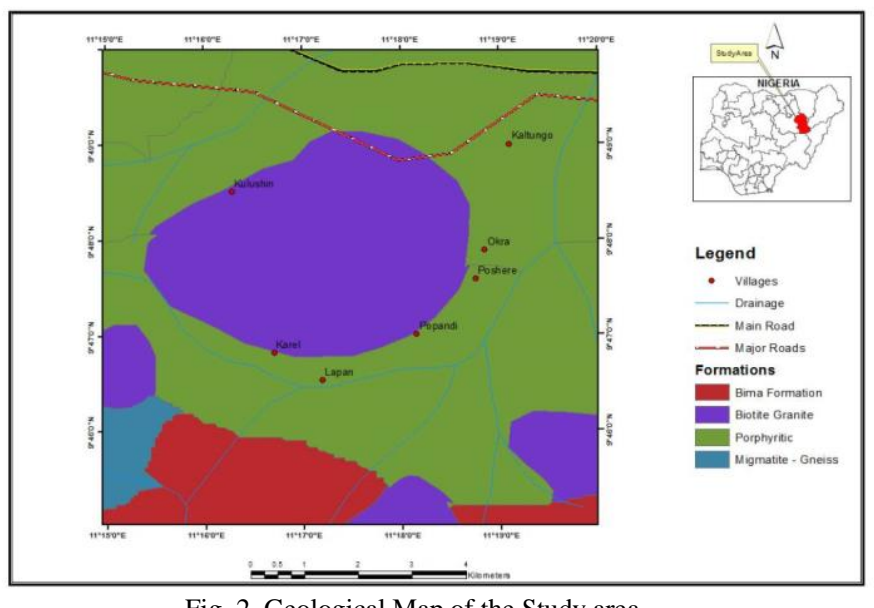

Fig. 2. Geological Map of the Study area.

Hydrogeology of the area is divided into groundwater and surface water. Groundwater is water that filled all pores and voids found within a geological formation. The occurrence and distribution of groundwater in an area is controlled by geological factors such as lithology, texture of the rocks and also the structures in the rocks, as well as climatic factors such as rainfall. Surface water in the study area occur in the form of streams and lakes. They serve as water supply sources for drinking and domestic uses. Most of the streams and lakes are seasonal. The streams and lakes are recharged by direct precipitation during the raining season.

Also, knowledge of the chemical constituents of the groundwater can aid in detecting its contamination, necessitating the decision of whether water treatment is necessary before human consumption.

\section{Methodology}

This involves collection of water samples from the study area. In sampling groundwater for quality analysis, plastic bottles were used. After rinsing the bottle with the same water to be sampled, four (4) samples were collected from boreholes and six (6) were collected from hand dug wells in rubber bottles. The filled samples bottles were placed in the cool box and were taken immediately to the laboratory for analysis. The samples were analyzed chemically using the following instrument the DR/2010 Spectrophotometer and Digital titrator. Meanwhile the $\mathrm{pH}$ meter and Total dissolve solid meter were used in the field to measure the $\mathrm{pH}$ of the water and Total Dissolve Solids in the water. The values obtained were compared with maximum permissible limit set by World Health Organization (WHO) standard 2011 to evaluate its suitability for drinking and domestic purpose (Table I).

\section{DisCUSSION OF RESUlT}

\section{A. Aquifer Parameters Calculated from Geophysical Data}

The aquifer parameters calculated from geophysical data like hydraulic conductivity $(\mathrm{K})$ and transmissivity $(\mathrm{T})$ are 
important for the management and development of groundwater resources. The hydraulic conductivity was estimated using the equation as given by [5].

Generally, the higher the transmissivity value of an aquifer, the better its productivity prospect [8]. Hydraulic conductivity is proportional to permeability. High permeability will be observed in aquifer zone with high hydraulic conductivity and also contaminants will be easily circulated [7].

The hydraulic conductivity calculated from the electrical resistivity sounding data for twenty-four (24) potential aquifer resistivity was contoured as shown in Fig. 3. The hydraulic conductivity values estimated from the VES results range between 4.24 to $72.63 \mathrm{~m} /$ day.

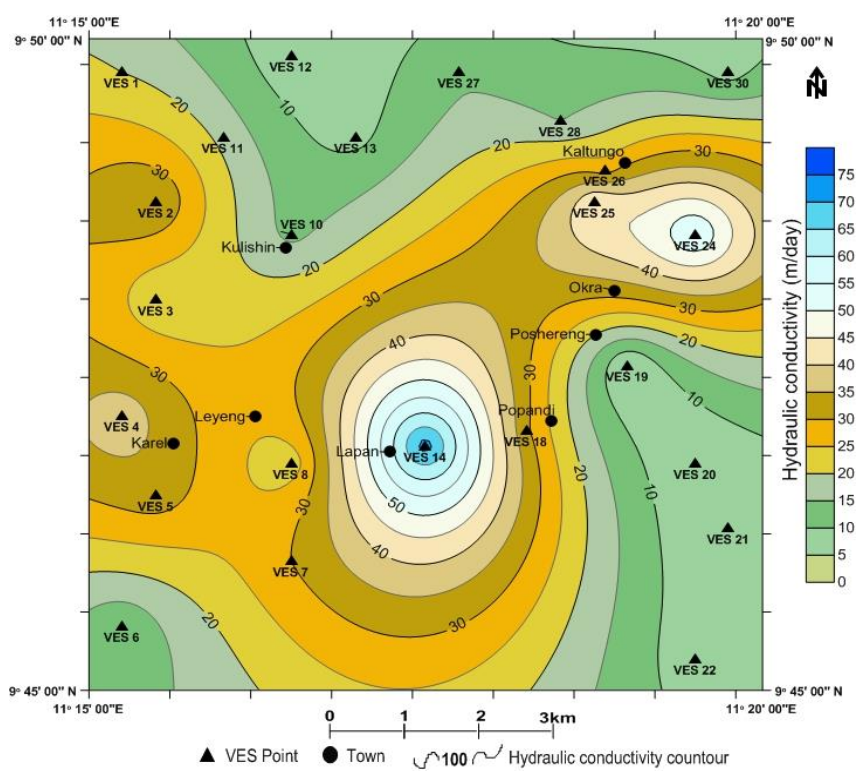

Fig. 3. Hydraulic conductivity contour map (contour interval $5 \mathrm{~m} /$ day).

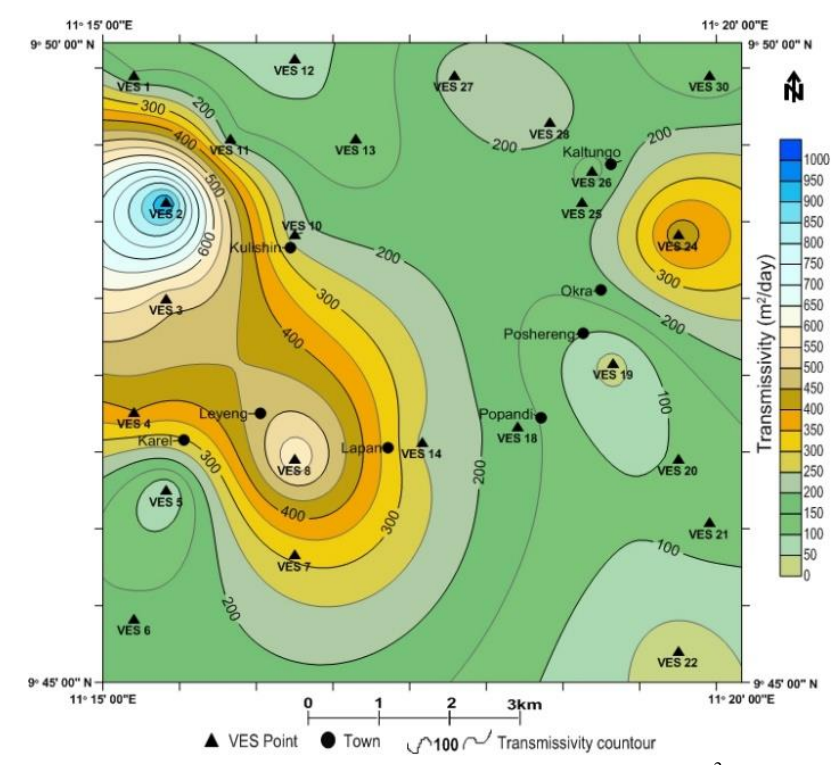

Fig. 4. Transmissivity contour map (contour interval $50 \mathrm{~m}^{2} /$ day).

Hydraulic conductivity depends on the intrinsic permeability of the material and on the degree of saturation. The maximum hydraulic conductivity values are observed at VES 14 toward the southern portion of the study area while the transmissivity values vary between $23.84 \mathrm{~m}^{2} /$ day and $964.0 \mathrm{~m}^{2} /$ day. Result of hydraulic conductivity and transmissivity calculated from the 24 VES points the result reveals that the productive water-bearing zone categorized as good potential zone occur in VES 23 and 8 at the northwest and south western part of the study area. The moderate groundwater potential zone has a range of value 87.22-440.98 $\mathrm{m}^{2} /$ day at VES points $1,4,6,7,10,11,12,13,14,18,20,21,24$, $25,26,27,28$ and 30 . The remaining parts of the study area were demarcated as low potential zone.

Pearson Correlation measures the degree of a linear relationship between two variables. The correlation coefficient assumes a value between -1 and +1 [13]. If one variable tends to increase as the other decreases, the correlation coefficient is negative. Conversely, if the two variables tend to increase together the correlation coefficient is positive. The larger the absolute value of the coefficient, the stronger the relationship between the variables.

For the Pearson correlation, an absolute value of 1 indicates a perfect linear relationship. A correlation close to 0 indicates no linear relationship between the variables. The sign of the coefficient indicates the direction of the relationship. If both variables tend to increase or decrease together, the coefficient is positive, and the line that represents the correlation slopes upward. If one variable tends to increase as the other decreases, the coefficient is negative, and the line that represents the correlation slopes downward. The Pearson correlation coefficient between transmissivity and Hydraulic conductivity given the correlation coefficient of 0.38 . This signifies that hydraulic conductivity is directly proportional to transmissivity. Fig. 5. Therefore, shows a good correlation between hydraulic conductivity and transmissivity.

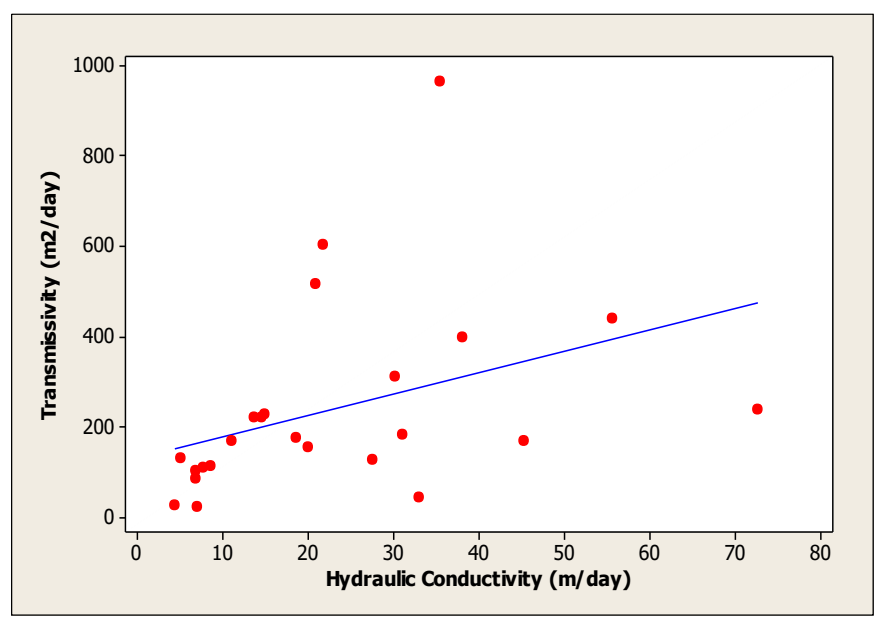

Fig. 5. Correlation between transmissivity and hydraulic conductivity.

\section{B. Water Quality Analysis}

Groundwater is not chemically pure, solution of substance filtered in the course of percolation through the soil and groundwater acquires some of these dissolved chemical constituents. Dissolved chemical constituent in water determine its usage for various purposes. The concentration of the dissolved constituents is compared to the standards of World Health Organization [12]. The hydro-geochemical parameters are presented in (Table I). The physical parameters revealed that $\mathrm{pH}$ values range from 6.5-7.2, colour range from 0.00-2.00, Turbidity (NTU) ranges 0.00-3.1, conductivity $(\mu \mathrm{s} / \mathrm{cm})$ ranges from $130-210$, total dissolved solids (TDS) ranges from 65-110. And Hardness $\mathrm{CaCo}_{3}$ 
ranges from 98-221.

The physical parameters such as $\mathrm{pH}$, Tempt. (OC) colour (TCU), Turbidity (NTU), Conductivity and TDS are within the permissible limit of WHO [12] standard, while Hardness $\mathrm{CaCo}^{3}$ ranges from 98-221 and mean value of 161.7 is above the permissible limit (Table I). Calcium $\left(\mathrm{Ca}^{2+}\right)$ mean concentration of $64.3 \mathrm{mg} / \mathrm{l}$ is below the acceptable limit of WHO. Sodium $\left(\mathrm{Na}^{+}\right)$mean overall value of $68.8 \mathrm{mg} / \mathrm{l}$ and range from $24-133 \mathrm{mg} / \mathrm{l}$ is below the permissible limit. Nitrate $\mathrm{No}^{3+}$ with mean value of $0.1 \mathrm{mg} / \mathrm{l}$ and range from 0 $0.3 \mathrm{mg} / \mathrm{l}$ is below the acceptable limit of (WHO). Iron $\left(\mathrm{Fe}^{2+}\right)$ with mean value of 0.4 is below the permissible limit. The concentration of copper $\left(\mathrm{Cu}^{2+}\right)$ ranges from $0.27-0.5$ and mean value of 0.386 is below the limit of WHO Standard.

The concentration of carbonate $\mathrm{Co}_{3}$ range from $55-170 \mathrm{mg} / \mathrm{l}$ is above the permissible limit. Sulphate $\left(\mathrm{SO}_{4}{ }^{2-} \mathrm{mg} / \mathrm{l}\right)$ range 38 $60 \mathrm{mg} / \mathrm{l}$ with mean value of $47 \mathrm{mg} / \mathrm{l}$ is within the permissible limit of (WHO). Chloride $\mathrm{Cl}^{-} \mathrm{mg} / \mathrm{l}$ range from $45-206 \mathrm{mg} / \mathrm{l}$ and overall mean of 96 is within the acceptable limit. Fluoride $\mathrm{F}^{-} \mathrm{mg} / \mathrm{l}$ mean value of 0.3 and range from $0.00-1.92$. The value in the sample point five is above the permissible limit of (WHO).

The result of the analysis of water samples collected from the ten selected bore holes and hand dug wells presented in (Table I) indicate that the $\mathrm{pH}$ value range from 6.5-7.2 $\mathrm{mg} / \mathrm{l}$. The $\mathrm{pH}$ value $6.5 \mathrm{mg} / \mathrm{l}$ at Lakolin and Karel (moderately acidic) to $7.2 \mathrm{mg} / \mathrm{l}$ (slightly acidic) at Poshereng and Lapandintai. Water sampled at Lakolin, Layeng, Karel, Lapan PHC, Aya, Lakanje and M/quarters exhibit acidic condition with values of $6.5,6.8,6.5,6.8,6.7,6.9$ and 6.6. Hand dug well at Poshereng 7.2 and Borehole at Lapandintai 7.0 exhibit alkalinity. The study shows a mean $\mathrm{pH}$ value of 6.82 which indicating an acidic solution. Physical analysis and evaluation indicate that temperature has a mean value of $31{ }^{\circ} \mathrm{C}$ in all the sample location. The colour of water in the area ranges from $0.00-2.00 \mathrm{mg} / \mathrm{l}$ with a mean value of $1.00 \mathrm{mg} / \mathrm{l}$. Measurement of turbidity in the area range from $0.00-3.1 \mathrm{mg} / \mathrm{l}$ and has a mean value of $1.2 \mathrm{mg} / \mathrm{l}$ and fall within the standard value for WHO [12]. Conductivity values ranges from $130-210 \mu \mathrm{s} / \mathrm{cm}$ and has a mean value of $174.5 \mu \mathrm{s} / \mathrm{cm}$ which falls within the recommended limit. (Table I) indicate TDS concentration of dissolved minerals in water and is an indication of the suitability of water for much type of uses. Total dissolved solid in the study area ranges from 65$110 \mathrm{mg} / \mathrm{l}$, and mean value of $87.7 \mathrm{mg} / \mathrm{l}$ which is moderate and falls within standard of WHO [12]. Total hardness $\left(\mathrm{CaCo}_{3}\right)$ in the study area ranges from $98 \mathrm{mg} / \mathrm{l}$ at Lakolin to $221 \mathrm{mg} / \mathrm{l}$ at Poshereng with a mean value of $161.7 \mathrm{mg} / \mathrm{l}$. The values of hardness indicate that the water in some part of the area is hard in nature. According to [11] that hardness value of 0 $75 \mathrm{mg} / \mathrm{l}$ is classified as soft, $75-150 \mathrm{mg} / \mathrm{l}$ as moderately hard, $150-300 \mathrm{mg} / \mathrm{l}$ as hard and $>300 \mathrm{mg} / \mathrm{l}$ as very hard. According to [10], water used in boilers should be soft and non-corrosive while laundry water should be colorless and soft. Water for industrial activities should be odorless, colorless, and free from suspended matter and microorganisms and of low iron and manganese content. Hardness of water limits its use for domestic, industrial, and agricultural activities. Water hardness can cause scaling of pots, boilers, and irrigation pipes, it may also cause health problems to human such as kidney failure [6].

Calcium concentration in the area ranges from $40-113 \mathrm{mg} / \mathrm{l}$ and mean value of $64.3 \mathrm{mg} / \mathrm{l}$. Sodium has a concentration level that range $24-133 \mathrm{mg} / \mathrm{l}$ and mean value of $68.8 \mathrm{mg} / \mathrm{l}$ which falls within the WHO standard for drinking water. Nitrate concentration has range of $0.00-0.3 \mathrm{mg} / \mathrm{l}$ and mean value of $0.1 \mathrm{mg} / \mathrm{l}$ falls within the standard of WHO [12]. Iron with concentration range from $0.0-1 \mathrm{mg} / \mathrm{l}$ and mean value of $0.04 \mathrm{mg} / \mathrm{l}$ falls within the standard limit. Carbonate with concentration range from $55-170 \mathrm{mg} / \mathrm{l}$ and mean value of $96.4 \mathrm{mg} / \mathrm{l}$. The values in sample location Lapan PHC, Poshereng and Lapandintai are above the permissible limit for WHO standard [12]. Sulphates, in the study area range from $38-60 \mathrm{mg} / \mathrm{l}$ and mean value of $47 \mathrm{mg} / \mathrm{l}$. Chloride concentration in the area ranges from $45-206 \mathrm{mg} / \mathrm{l}$ with a mean value of $96 \mathrm{mg} / \mathrm{l}$ chloride concentration falls within WHO standard [12]. Fluoride concentration in the area range from $0.00-1.9 \mathrm{mg} / \mathrm{l}$. However, the result revealed that the concentration is above the permissible limit of WHO [12] in Poshereng (HW5) with $1.9 \mathrm{mg} / \mathrm{l}$. The effect of usability of water with fluoride concentration of between $0.5-1.5 \mathrm{mg} / \mathrm{l}$ in drinking water has a beneficial effect on the structure and resistance to decay of children teeth. Fluoride in excess of $1.5-4.0 \mathrm{mg} / \mathrm{l}$ promote dental fluorosis. Fluoride of $4.0-10 \mathrm{mg} / \mathrm{l}$ may result to dental fluorosis, skeletal fluorosis (pain in back and neck bones).

The geochemistry of fluoride in groundwater and dental health communities, particularly those depending on groundwater for their drinking water supplies is one of the best known relationship between geochemical and health. Fluoride is considered to be an essential element [13] although dental health problems may arise from an excess of fluoride. Many waters supply schemes particularly in developing countries where hand dug wells and deep boreholes form as much are harmful to dental health [2]. For most trace elements (required by man, food is the principal source). In the case of fluoride, however, much of the input into the human body is from drinking water and geochemistry of fluoride in groundwater shows the impact of fluoride on health.

High concentration of fluoride could be due to leaching from rocks rich in fluoride. Fluoride is naturally occurring element found in rock, soil, air, and vegetation. Fluoride in the surface and groundwater are derived from:

$>$ Rainwater, which may acquire a small amount of fluoride from marine aerosols and continental dust.

$>$ Industries emissions such as freons, organic fluoride and dust in cryolite factories.

$>$ Leaching of rocks rich in fluoride, e.g., granite, alkali rocks, volcanic ash, and bentonites.

>Dissolution of fluorides from volcanic gases by percolating groundwater along faults and joints of great depth and discharging as fresh and mineral springs.

High concentration of fluoride in water above the permissible limit may induce skeletal and dental disorder, and cause harm to kidneys, nerves and muscles and low concentration of fluoride in plants can cause damage in leafs and growth retardation in plant. 
TABLE I: GEOCHEMICAL DATA OF TEN WATER SAMPLES AND WATER QUALITY STANDARD

\begin{tabular}{|c|c|c|c|c|c|c|c|c|c|c|c|c|c|c|c|c|c|c|}
\hline \multirow[b]{2}{*}{$\begin{array}{c}\mathrm{S} / \mathrm{N} \\
\mathrm{O}\end{array}$} & \multirow[b]{2}{*}{$\begin{array}{c}\text { Sample } \\
\text { locations }\end{array}$} & \multirow[b]{2}{*}{$\begin{array}{l}\text { Sample } \\
\text { source }\end{array}$} & \multicolumn{6}{|c|}{ Physical parameters } & \multicolumn{5}{|c|}{ Chemical parameters cations $(\mathrm{mg} / \mathrm{l})$} & \multicolumn{5}{|c|}{ Chemical parameters anions $(\mathrm{mg} / \mathrm{l})$} \\
\hline & & & $\mathrm{pH}$ & $\begin{array}{c}\text { Tempt } \\
{ }^{\circ} \mathrm{C}\end{array}$ & $\begin{array}{c}\text { Colour } \\
\text { TCU }\end{array}$ & $\begin{array}{c}\text { Turbidity } \\
\text { NTU }\end{array}$ & $\begin{array}{c}\text { Conduct. } \\
\mu \mathrm{s} / \mathrm{cm}\end{array}$ & $\begin{array}{l}\text { TDS } \\
\mathrm{Mg} / \mathrm{l}\end{array}$ & $\begin{array}{c}\mathrm{CaCO}_{3} \\
\mathrm{mg} / \mathrm{l}\end{array}$ & $\begin{array}{l}\mathrm{Ca}^{2+} \\
\mathrm{Mg} / \mathrm{l}\end{array}$ & $\begin{array}{l}\mathrm{Na}^{+} \\
\mathrm{Mg} / \mathrm{l}\end{array}$ & $\begin{array}{l}\mathrm{No}^{3+} \\
\mathrm{Mg} / \mathrm{l}\end{array}$ & $\mathrm{Fe}^{2+}$ & $\mathrm{CO}_{3}$ & $\mathrm{SO}_{4}{ }^{2}$ & $\mathrm{Cu}^{2+}$ & $\mathrm{Cl}^{-}$ & $\mathrm{F}^{-}$ \\
\hline 1 & Lakolin & HW1 & 6.5 & 31 & 2.00 & 3.0 & 210 & 105 & 98 & 40 & 30 & 0.2 & 0.1 & 55 & 50 & 0.30 & 45 & 0.0 \\
\hline 2 & Kulishin & HW2 & 7.2 & 31 & 1.50 & 2.5 & 170 & 85 & 140 & 56 & 24 & 0.1 & 0.0 & 82 & 40 & 0.42 & 36 & 0.0 \\
\hline 3 & Layeng & HW3 & 6.8 & 31 & 2.00 & 2.5 & 165 & 82 & 145 & 57 & 70 & 0.2 & 0.0 & 85 & 42 & 0.36 & 110 & 0.0 \\
\hline 4 & Karel & HW4 & 6.5 & 31 & 0.20 & 0.3 & 190 & 95 & 125 & 50 & 32 & 0.0 & 0.0 & 77 & 60 & 0.43 & 48 & 0.0 \\
\hline 5 & Poshereng & HW5 & 7.2 & 31 & 2.10 & 3.1 & 130 & 65 & 221 & 88 & 133 & 0.3 & 0.2 & 133 & 37 & 0.40 & 206 & 1.9 \\
\hline 6 & $\begin{array}{c}\text { Mqts } \\
\text { Kaltungo }\end{array}$ & HW6 & 6.6 & 31 & 0.20 & 0.2 & 190 & 95 & 146 & 56 & 65 & 0.0 & 0.0 & 87 & 52 & 0.39 & 100 & 0.0 \\
\hline 7 & PhcLapan & BH1 & 6.8 & 31 & 0.10 & 0.2 & 200 & 110 & 200 & 80 & 75 & 0.0 & 0.0 & 120 & 38 & 0.0 .5 & 115 & 0.0 \\
\hline 8 & Aya & $\mathrm{BH} 2$ & 6.7 & 31 & 1.80 & 0.2 & 180 & 90 & 132 & 53 & 115 & 0.0 & 0.1 & 76 & 48 & 0.33 & 178 & 0.7 \\
\hline 9 & Lakanje & $\mathrm{BH} 3$ & 6.9 & 31 & 0.00 & 0.0 & 160 & 80 & 126 & 50 & 110 & 0.2 & 0.0 & 76 & 45 & 0.27 & 70 & 0.3 \\
\hline \multirow[t]{4}{*}{10} & $\begin{array}{c}\text { Lapan } \\
\text { dintai }\end{array}$ & BH4 & 7.0 & 31 & 0.10 & 0.0 & 150 & 70 & 284 & 113 & 34 & 0.0 & 0.0 & 170 & 58 & 0.46 & 52 & 0.0 \\
\hline & Mean & & 6.82 & 31 & 1.00 & 1.2 & 174.5 & 87.7 & 161.7 & 64.3 & 68.8 & 0.1 & 0.04 & 96.4 & 47 & 0.38 & 96 & 0.3 \\
\hline & \multicolumn{2}{|c|}{ Range } & $\begin{array}{l}6.5- \\
7.2\end{array}$ & & $\begin{array}{l}0.00- \\
2.00\end{array}$ & $0.00-3.1$ & $130-210$ & $\begin{array}{l}65- \\
110\end{array}$ & $98-221$ & $\begin{array}{l}40- \\
113\end{array}$ & $\begin{array}{l}24- \\
133\end{array}$ & $\begin{array}{c}0.0- \\
0.3\end{array}$ & $\begin{array}{c}0.0- \\
1.1\end{array}$ & $\begin{array}{l}55- \\
170\end{array}$ & $\begin{array}{c}38- \\
60\end{array}$ & $\begin{array}{c}0.27- \\
0.5\end{array}$ & $\begin{array}{l}45- \\
206\end{array}$ & $\begin{array}{l}0.0 \\
1.9\end{array}$ \\
\hline & \multicolumn{2}{|c|}{$\begin{array}{c}\text { WHO [12] } \\
\text { permissible value } \\
(\mathrm{mg} / \mathrm{l})\end{array}$} & $\begin{array}{l}6.5- \\
8.5\end{array}$ & & 15 & 5 & 1000 & 1000 & 150 & 200 & 200 & $2-50$ & 0.2 & 100 & 500 & 2.0 & 250 & 1.5 \\
\hline
\end{tabular}

\section{Groundwater Flow Direction}

Hydraulic head map of the area was produced by joining points of equal hydraulic heads and piezometrics lines were drawn at a right angle by an arrow drawn perpendicular to the contour line to indicate groundwater flow direction. The contour map showing the groundwater flow direction Fig. 6 in the area was produced using elevation height of each well and static water level. These hydraulic head values are used on topographic map, relating the hydraulic head values to the borehole location. Groundwater generally flows from area of high surface elevation, where rocks generally outcrop, to areas of low surface elevation, where rocks are usually buried under more or less thick overburden. The points are contoured with an interval of $5 \mathrm{~m}$. The hydraulic head is the energy available for flow. The hydraulic head map of distribution of the study area indicates groundwater flow from recharge area around Poshereng, Popandi, Lapan. The groundwater flow direction in the study area is in the NW-SE and E respectively.

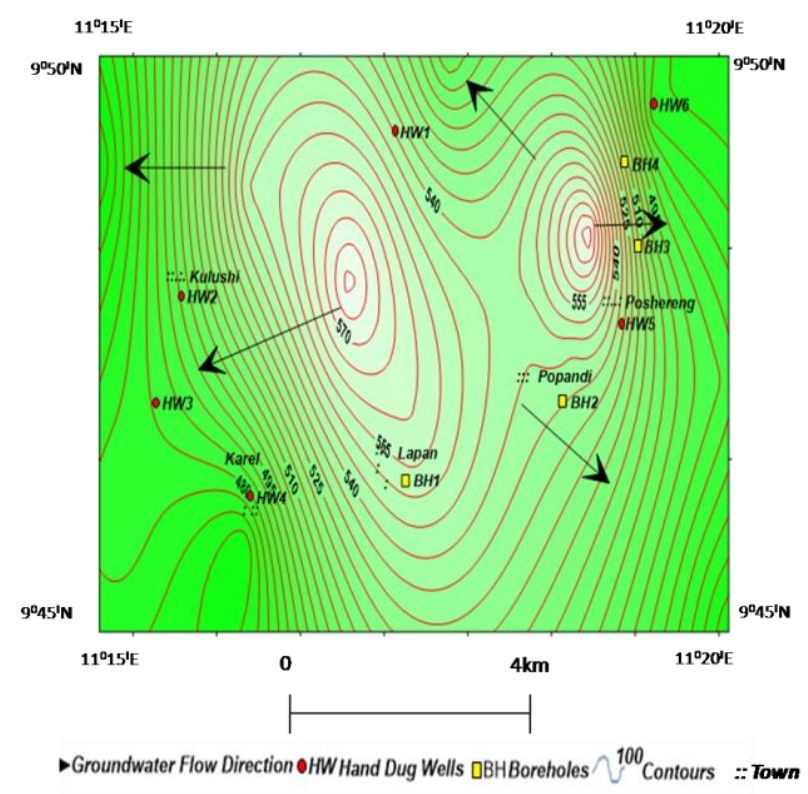

Fig. 6. Groundwater Flow Directions of Kaltungo and Environs (contour interval $5 \mathrm{~m}$ ).

\section{CONCLUSION}

Hydraulic conductivity values estimated from the VES results range between $4.24 \mathrm{~m} /$ day to $72.63 \mathrm{~m} / \mathrm{day}$. The maximum hydraulic conductivity values were observed at VES 14 toward the southern portion of the study area while the transmissivity values vary between $23.84 \mathrm{~m}^{2} /$ day and $964.0 \mathrm{~m}^{2} /$ day and has helped in determining areas of similar geologic setting and water quality.

The analysis of water samples collected from six selected hand dug wells and four boreholes revealed an average $\mathrm{pH}$ value of $6.82 \mathrm{mg} / \mathrm{l}$ which indicate an acidic condition, mean colour value of $1.00 \mathrm{mg} / \mathrm{l}$, mean turbidity value of $1.2 \mathrm{mg} / \mathrm{l}$, mean conductivity value of $174.5 \mathrm{mg} / \mathrm{l}$, mean TDS value of $87.7 \mathrm{mg} / \mathrm{l}$ indicating that the water is desirable. The mean concentration of calcium carbonate value of $161 \mathrm{mg} / \mathrm{l}$, mean value of calcium $64.3 \mathrm{mg} / \mathrm{l}$, mean value of sodium $688 \mathrm{mg} / \mathrm{l}$, mean value of nitrate $0.1 \mathrm{mg} / \mathrm{l}$, mean value of iron $0.04 \mathrm{mg} / \mathrm{l}$, mean value of carbonate $96.4 \mathrm{mg} / \mathrm{l}$, mean value of sulphates $47 \mathrm{mg} / \mathrm{l}$, chloride mean value $96 \mathrm{mg} / \mathrm{l}$ and fluoride concentration sample location five in the study area is above the permissible limit of WHO standard. Therefore, the water in those areas is not fit for human consumption without proper treatment. In the case of fluoride in the affected part of the study area Kaltungo and Environs great caution should be executed in the selections of a well and borehole site to reduce fluoride contamination from the surrounding and other geologic formation. This can be achieved by taken the samples of the rock at each depth during the drilling process and analyzed them. The water flow direction from high surface elevation to low surface elevation in the study area is in the NW-SE and E to Southwest direction.

\section{ACKNOWLEDGMENT}

The authors are grateful to Adamawa State Ministry of Water Resource for making availability of the instruments, support and assistance provided for the completion of this work.

\section{CONFLICT OF INTEREST}

Authors declare that they do not have any conflict of interest. 


\section{REFERENCES}

[1] Allix P. Environments Mesozoiques de la partie nord orientation du fosse de la benoue (Nigeria). Stratigraphic Sedimentology - Evolution Geolodynamique. These de $3 \mathrm{cmc}$ cycle Marseille st Jerome (B). 21, pp 200, 1981.

[2] Dissanayake C. B. Medical geochemistry of tropical environment.Earth Science Review, 1999: 231.

[3] Falconer D. J. The Geology and geography of northern Nigeria Macmillan, London, 1911:294-295.

[4] Gombe State Rural Water Supply and Environmental Sanitation Agency. Unpublished borehole data report, 2008.

[5] Heigold P. C., Gikeson R. H., Cartwright K. and Reed P. C. Aquifer transmissivity from surficial electrical methods. Groundwater, 1979;17(4):338-345.

[6] Ishaku J. M., Ahmed A.S. and Abdulhakeem A. Mapping of water quality Index using GIS in kaltungo area, NE Nigeria. Journal of environmental Sciences and resources management, 2011;3:94-96.

[7] Kazakis N., Vargemezis G., Voudouris K. S. Estimation of hydraulic parameters in a complex porous aquifer system using geoelectrical methods. Science of the Total Environment, 2016;550:742-750.

[8] Nggada I. S. and Nur A. Assessment of groundwater quality of Biu and Environs North Eastern Nigeria. International Journal of Science and Technology Research, 2017;6:5-14.

[9] Offodile M. M. The occurrence and exploitation of groundwater in Nigeria basement complex. J. mining Geol. 1991: 131-146.

[10] Okafor D. W. The physio-chemical qualities of water of River Bakoji catcment area of Niger State. Nigeria. Jour. Water Res., 1994;4(182):22-27.

[11] Sawyer C. N., and McCarty P.I. Chemistry for Sanity engineers. 2nd edition, McGraw-Hill, New York" 1967.

[12] WHO. Guide line for drinking water quality fourth edition Geneva Swirtzerland, 2011.

[13] Wood J. M. Biological Cycles for toxic elements in the environment science, Science, 1974;183:1649-1052. 